\title{
PSYCHOEDUCATION THERAPY REDUCES BURDEN AND IMPROVES FAMILY ABILITY IN CARING FOR MENTAL RETARDATION CHILDREN
}

\author{
(Terapi Psikoedukasi Menurunkan Beban dan Meningkatkan Kemampuan Keluarga dalam \\ Merawat Anak Retardasi Mental)
}

\author{
Sutinah*, Nofrida Saswati** \\ STIKES Harapan Ibu, Jambi \\ E-mail: nofridasaswati@gmail.com
}

\begin{abstract}
ABSTRAK
Pendahuluan: Anak retardasi mental memiliki fungsi intelektual dibawah rata-rata, tidak adekuatnya perilaku merawat diri, bersosialisasi, berkomunikasi, keterampilan adaptif, peran serta dan dukungan dari keluarga diperlukan untuk meningkatkan kemandirian anak sehingga kemampuan meningkat dan beban keluarga menurun. Berbagai terapi dapat dilakukan meningkatkan kemampuan keluarga diantaranya terapi psikoedukasi keluarga. Tujuan penelitian mengetahui pengaruh terapi psikoedukasi terhadap beban dan kemampuan keluarga dalam merawat anak retardasi mental di SDLB Prof. Dr. Sri Soedewi Masjchun Sofwan, SH Kota Jambi. Metode: Jenis penelitian kuantitatif quasi experimental, non equivalent, control group pre test dan post test design. Sampel sebanyak 64 responden yang terdiri dari 32 kelompok intervensi dan 32 kontrol dengan tehnik proportional random sampling. Pengumpulan data menggunakan kuesioner dengan metode wawancara terstruktur. Hasil: Hasil penelitian menunjukkan terjadi penurunan beban dan peningkatan kemampuan keluarga dalam merawat anak retardasi mental setelah mendapatkan terapi psikoedukasi. Terapi psikoedukasi merupakan terapi yang dapat dilakukan untuk keluarga dengan anak gangguan psikososial dimana saling bertukar informasi tentang perawatan kesehatan mental akibat penyakit yang dialami, membantu anggota keluarga mengerti tentang penyakit. Diskusi: Direkomendasikan untuk melakukan penelitian dengan mengkombinasikan antara terapi psikoedukasi dan terapi suportif terhadap dukungan psikososial keluarga dengan anak retardasi mental.
\end{abstract}

Kata Kunci: Beban, kemampuan merawat, retardasi mental, psikoedukasi

\begin{abstract}
Introduction: Children with mental retardation have intellectual functioning below average, inadequate self-care behaviors, socializing, communication, adaptive skills, participation and family support is needed to enhance the independence of the child so that the capability increased and decreased the family burden. Various therapists can be treated to increase the capability of families including family psyche-education therapy. This study is aimed to identify the influence of psychoeducation therapy to the family burden and the capability of families in caring for mentally retarded children in SDLB Prof. Dr. Sri Soedewi Masjchun Sofwan, SH Jambi. Method: Quantitative research quasi-experimental, nonequivalent, control group pre-test, and post-test design. A sample of 64 respondents consisting of 32 intervention and 32 control with proportional random sampling technique. The data was collected using a structured questionnaire with interview method. Result: The results showed a decrease of the burden and increased the capability of a family in caring for children with mental retardation after psychoeducation therapy. Psycho-education therapy is a therapy that can be implemented for a family with psychosocial disorders where exchanged information on mental health care due to the illness suffered, help family members to understand about the disease. Discussion: It is recommended to conduct research that combines psychoeducation therapy and supportive therapy to psychosocial support family of children with mental retardation.
\end{abstract}

Keywords: burden, caring capability, mental retardation, psycho-education

\section{INTRODUCTION}

Children with mental retardation need special attention and care of the family. Lumbantobing (2011), said mental retardation $(\mathrm{RM})$ is a state of mental development incompleteness and stalled. Carson (2000), mental retardation is inadequate self-care behaviors, socializing, communication and other adaptive skills. Videback (2007), mental retardation is intellectual functioning below the average for the area accompanied by limitations in adaptive functioning.

Mental retardation is quite numerous, either in developed and developing countries. The prevalence of mental retardation in the world 1-3\% (Kathleen, 2004). Francis and
Great Britain from 1.5 to $8.6 \% \quad 1-8 \%$ (Muttaqin, 2011). According to Dixon (2013), mental retardation occurs in children of school age 6-14 years, the incidence of mild mental retardation $85 \%$, moderate $10 \%, 4 \%$ by weight, a weight of 1-2\%. Behrman (2000), Indonesia prevalence of 3\%. Maramis (2011), said that the number of outstanding school students (SLB) in Indonesia there are 62.011 children, $60 \%$ of them were male. Mental retardation is also outspread in Jambi. According to the Social Department (2015), there were 1,386 people scattered ten places of the district and city. There were 333 of children with mental retardation (24.02\%) scattered in Sakti Unggul Autism 35, Kiddy 
Autism Centre 41, Yayasan Bunga Bangsa 50 and SLB Sri Soedewi Masjchun Sofwan, SH Jambi 207.

Children and adolescent with mental retardation will depend on participation and full support of the family. But in fact, the family has some obstacles in carrying out their role and provide support (Heward, 2011). Efforts could be implemented to overcome these obstacles is to provide health education, information dissemination, conduct psychoeducation, provide information to families about the use of health facilities (Utami, 2013).

The related research according to Hasmila (2011), in Aceh on the effect of therapy Family psycho-education against the burden and capability of treating clients stocks showed a decrease of the burden on families and increased the ability of families to take care of after therapy. Ahmmed, M. (2011), in Bangladesh on Impact of Psycho-Education and Support Program for Parents of Children with Disability Intellectual the results showed that the ability of parents with RM children had increased significantly with the results $7,21 \mathrm{p}<0.001$. Therefore, researchers aimed to compare:

1. The characteristics of parents and mentally retarded children in the intervention group and the control group in SDLB Prof. Dr. Sri Soedewi Masjchun Sofwan, SH Jambi.

2. The burden and the ability of families in caring for mentally retarded children in the intervention group and the control group before and after psychoeducation therapy in SDLB Prof. Dr. Sri Soedewi Masjchun Sofwan, SH Jambi.

3. The difference in the burden and the ability of families in caring for children with mental retardation in the intervention group and the control group before and after therapy psycho-education in SDLB Prof. Dr. Sri Soedewi Masjchun Sofwan, SH Jambi.

The urgency of research is to determine the burden and the capability of a family in caring for children with mental retardation after treated with psycho-education therapy.

\section{METHODS}

This study consists of several variables, therapy psycho-education is the independent variable (intervention) is, and the dependent variable consists of the burden and the capability of families in caring for children with mental retardation.

This research is a quantitative quasiexperimental, nonequivalent, control group pre-test and post-test design. Sampling technique used total sampling from grade four to grade six in SDLB Prof. Dr. Sri Soedewi Masjchun Sofwan SH in Jambi. Samples were families of children with mental retardation with the inclusion criteria consisted of 1) parents who have children with mental retardation. 2) parents who cared directly and live in one house with the kids with mental retardation. 3) parents who can write and read. 4) willing to participate fully. 5) willing to become respondent 6) cooperative. The sample size in this study to test determined based on the estimated mean difference two groups in pairs, with the formula (Dahlan, 2011), the total is 29 parents. To anticipate the possibility of sample drop out, the number of samples plus $10 \%$ of the estimated amount of sample, then obtained samples of 32 parents in the intervention and control, therefore, the total sample is 64 parents.

The procedure of research that does client ethical advance, while the activity research as follows: Week I researchers administering study license, researchers conducted a data collection through stages: 1) select respondents based on criteria. 2) provide an explanation of the purpose, process, expectations from this study clearly and give a chance to ask. 3) if they are willing to participate and sign the Informed Consent. 4) determine the intervention and control groups were taken out of from class 4,5 and 6. 6) perform the contract, Week I researchers conducted a pretest and general therapy for 5 days in the intervention group, carried out by 3 therapists where each therapist is responsible for 10 to 11 parents. The therapist came to their parent's house every day as much as 2-3 parents. Week II researchers conducted a pretest and general therapy for 1 day in the control group performed by 3 therapists; each therapist is responsible for one group.

Week II and III researchers conduct psycho-education therapy session 1 for 5 days. Week III researchers conduct psycho education therapy session 2 for 5 days. Week IV researcher conducts psycho-education therapy session 3 for 5 days. Week IV and V researchers conduct psycho-education therapy sessions 4 for 5 days. Week $\mathrm{V}$ and VI 
researchers conduct psycho-education therapy 5 sessions for 5 days after post-test. Carried out by 3 therapists where each therapist is responsible for 10 to 11 families. The therapist came to their family home every day as much as 2-3 families. Week VI and VII researchers conduct post-test and psycho-education therapy, each session conducted for 1 day. Performed by 3 therapists, each therapist is responsible for one group.

After the researchers conducted the research, further research data is analyzed by univariate and bivariate, previous researchers conduct the equivalence test to notice the homogeneity of the two groups, and then analyzed Paired t-tests and Independent T-test.

\section{RESULTS}

Characteristics of parents of children with mental retardation are composed of four sub-variables: age, education, household income and family type. Characteristics of the parents in the form of numerical data are age, calculated by the central tendency (mean, median, standard deviation, minimum valuemaximum and $95 \%$ Confidence Interval) can be viewed in table 1 . The average age of parents who have children with mental retardation was 42.28 years old $(95 \%$ CI: 39.81-44.75), with a standard deviation of 9.902 years. The age of the youngest is 25 years old, and the oldest is 61 years old. Based on the estimation interval can be concluded that $95 \%$ assured that the average age of the parents was 39.81 up to 44.75 years (Table 1 ).

Table 2 shows more than half of the parents have a low education level (57.8\%)with the majority of family incomes is below the UMP $(54.7 \%)$, while most of the family type is shaped core family $(62.5 \%)$.

Characteristics of children with mental retardation is composed of three sub-variables: age, gender, and classification of mental retardation. Characteristics of children in the form of numerical data are age, calculated by the central tendency (mean, median, standard deviation, minimum value-maximum and $95 \%$ Confidence Interval) can be seen in table 3 .

Table 3 shows the results of analysis reveals the average age of children with mental retardation is 11,38 years (95\% CI:10.84-
11.91), with a standard deviation of 2,142 years. The youngest age of 6 years old and the oldest 15 years. From the interval estimation can be concluded that $95 \%$ believed that the average age of children with mental retardation 10.84 up to 11.91 years. Table 4 shows the majority of children with mental retardation is male $(54.7 \%)$ and classified as a mild mental retardation $(56.2 \%)$. Table 5 shows the average burden on families of children with mental retardation before treated with intervention in the treatment group was 50.91, whereas in the control group the mean of a load on families is 54.22. The table shows the average total of family capability in caring for children with mental retardation before treated with intervention in the treatment group was 66.69 (Table 6).

The total average of family capability in caring for children with mental retardation before treated with intervention in the treatment group was 72.03 (Table 7). The table shows the average burden on families of children with mental retardation after treated with intervention in the treatment group was 47.09 , whereas in the control group that the average burden on a family is 53.38. Based on these results it can be concluded in accordance with the standards of a load on a family is in medium category (Table 8). Table 9 shows the total of average capability in caring about treated with intervention in the treatment group was 66.53. Table 10 demonstrates the total of average capability in caring about treated with intervention in the control group was 71.84. Table 11 indicates that there is a decrease of burden and the increase of family capability in caring for children with mental retardation in the intervention group, whereas in the control group there is a reduction of the burden and the reduction of family capability in caring for children with mental retardation.

Table 12 shows that there are significant differences between the burden of intervention and control groups after treated with psychoeducation therapy. There is no significant difference of family capability of intervention and control groups after treated with psychoeducation therapy.

Table 1 Analysis of Characteristics Parents of Children With Mental Retardation By Age ( $\mathrm{n}=64)$

\begin{tabular}{llcc}
\hline Variable & Mean & Median & SD 95\% CI Min-Max \\
\hline Age & 42.28 & 43.009 .902 & $39.81-44.7525-61$ \\
\hline
\end{tabular}


Table 2 Characteristics Frequency Distribution on Parents of children With Mental Retardation By Education, Income And Family Type $(n=64)$

No. Characteristics Category f $100 \%$

\begin{tabular}{lll}
\hline 1. Education & a. Low 3757.8 \\
& b. High 2742.2 & \\
2. A family income. & a. <UMP $35 \quad 54.7$ \\
& b. > UMP $29 \quad 45.3$ \\
3. A family types & a. Great family $24 \quad 37.5$ \\
& b. The nuclear family $40 \quad 62.5$ \\
\hline
\end{tabular}

Table 3 Characteristics Analysis of Children with Mental RetardationByAge $(n=64)$

\begin{tabular}{lll}
\hline Variable & \multicolumn{2}{l}{ Mean Median SD 95\%CI Min-Max } \\
\hline Age & $11: 3811: 002142$ & $10.84-11.916-15$ \\
\hline
\end{tabular}

Table 4 Frequency Distribution Characteristics of Children with mental retardation By Sex and The

Classification of Retardation Mental $(\mathrm{n}=64)$

No. Characteristics Category f $100 \%$

\begin{tabular}{lll}
\hline 1. Gender a. Male 3554.7 & \\
b. Female 2945.3 & & \\
2. Classification a. Mild mental & 36 & 56.2 \\
mental retardationretardation & & \\
b. Mental retardation 28 28.8 & \\
currently
\end{tabular}

Table 5 Burden Analysis on families of children with mental Retardation Before Treated With The Intervention in Treatment and Control Group $(\mathrm{n}=64)$

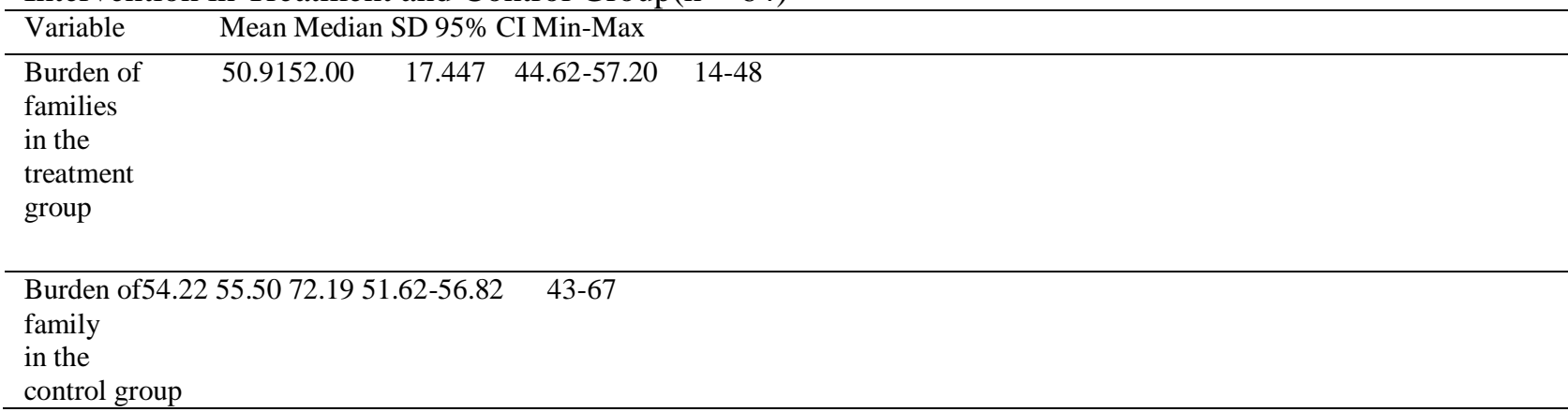

Table 6 Analysis of Family Capabilities in Caring for Children with mental Retardation Before Treated With Intervention in Treatment Group $(\mathrm{n}=32)$

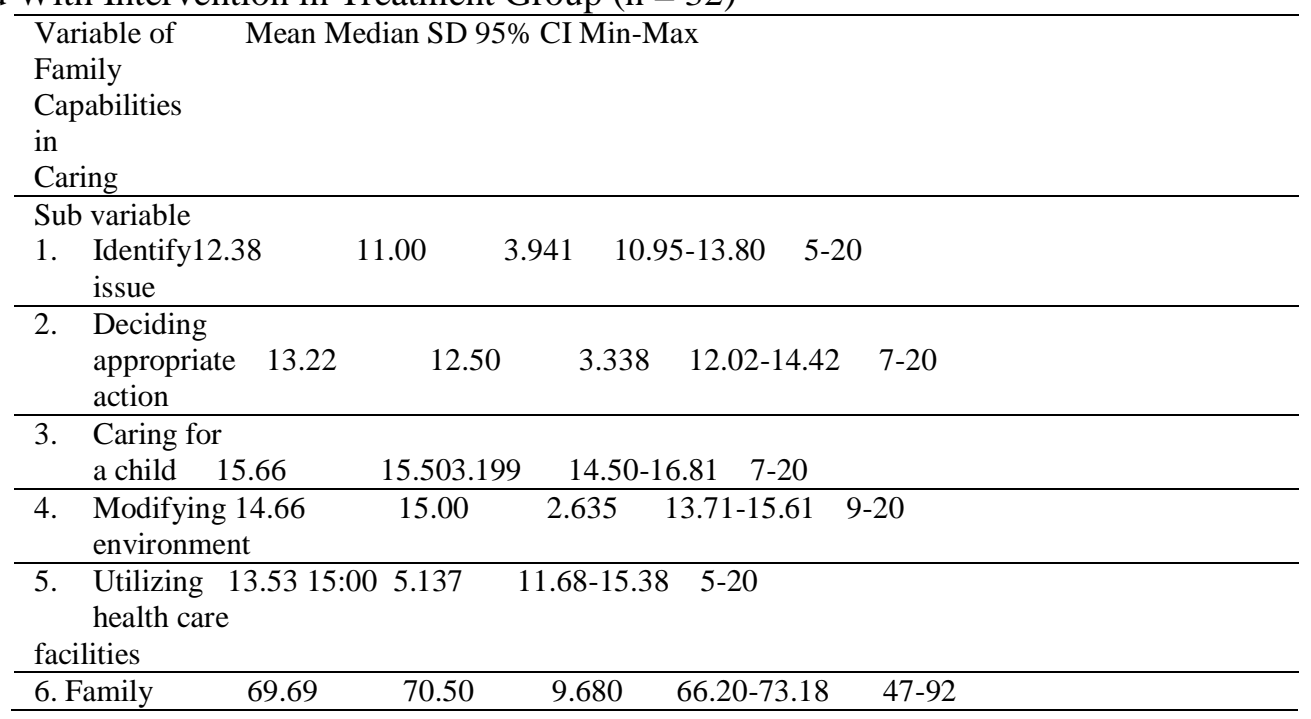


ability in

caring children

with mental

retardation

Table 7 Analysis of Family Capabilities in Caring for Children With Mental Retardation Before Treated With Intervention in Control Group $(n=32)$

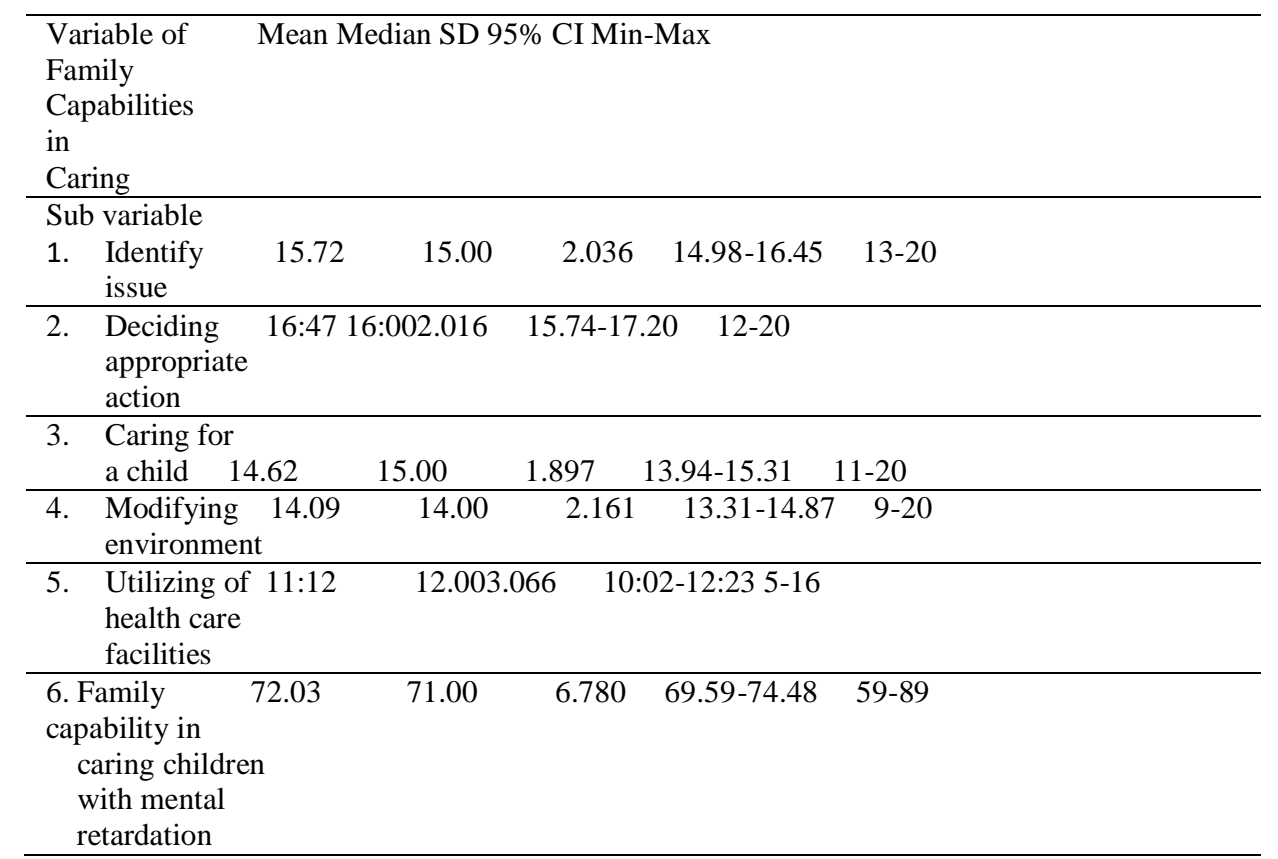

Table 8 Family Burden Analysis of children with Mental Retardation After Treated With Intervention in Treatment and Control Group $(n=64)$

\begin{tabular}{|c|c|c|c|}
\hline Variable & Mean Median SI & 95\% CI Min-Max & \\
\hline $\begin{array}{l}\text { Burden on } \\
\text { family } \\
\text { in the } \\
\text { group } \\
\text { treatment }\end{array}$ & $\begin{array}{ll}47.09 & 50.00\end{array}$ & $15.753 \quad 41.41-52.77$ & $14-72$ \\
\hline $\begin{array}{l}\text { Burden on } \\
\text { family In } \\
\text { control } \\
\text { group }\end{array}$ & 53.3852 .50 & $50.80-55.95$ & $42-66$ \\
\hline
\end{tabular}

Table 9 Family Capabilities Analysis in Caring for Children With Mental Retardation After Treated With Intervention in Treatment Group $(\mathrm{n}=32)$

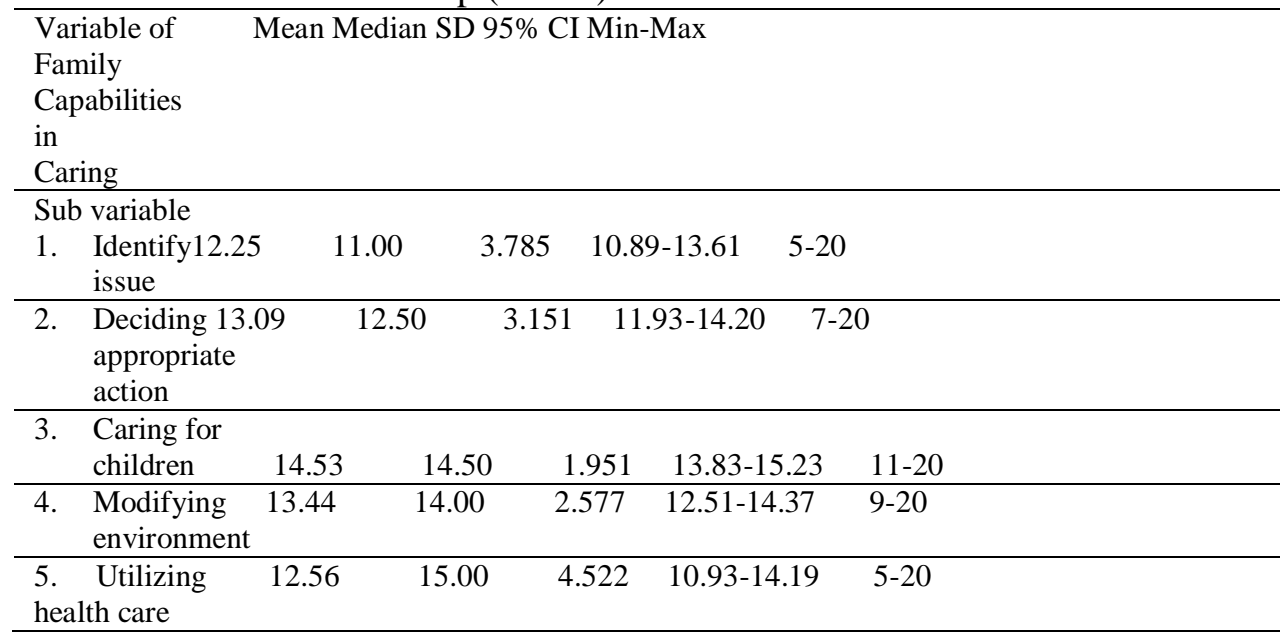




\begin{tabular}{|c|c|c|c|}
\hline facilities & & & \\
\hline $\begin{array}{l}\text { 6. Family } 66.53 \\
\text { capability in } \\
\text { caring children } \\
\text { with mental } \\
\text { retardation }\end{array}$ & $\begin{array}{ll}67.50 & 8.643\end{array}$ & $63.41-69.65$ & $47-81$ \\
\hline
\end{tabular}

Table 10 Family Capability Analysis in Caring for Children With Mental Retardation After treated With Intervention in Control Group $(n=32)$

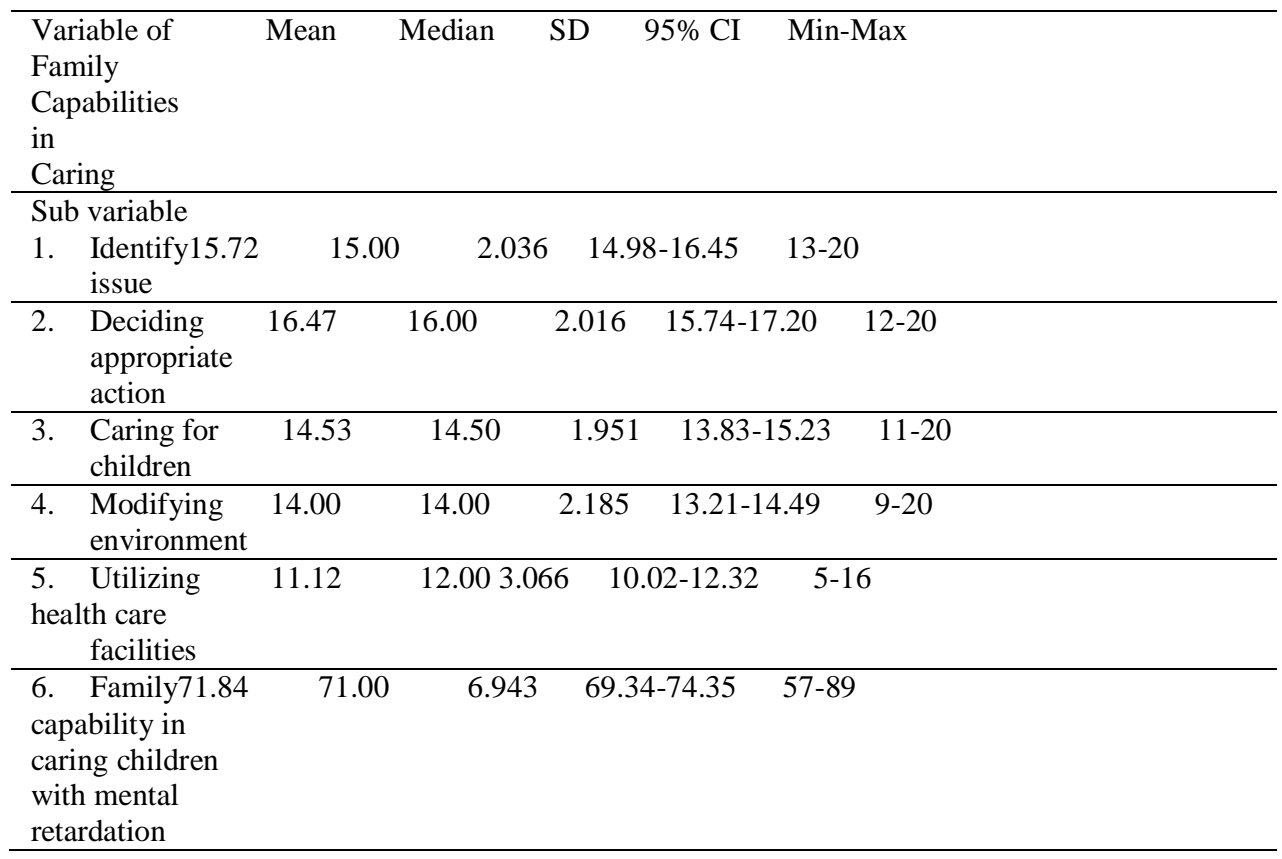

Table 11 Burden Differences and The Family Capability in Caring For Children With Mental Retardation Between Before and After Treated With Therapy in Treatment and Control Group ( $\mathrm{n}=$ 64)

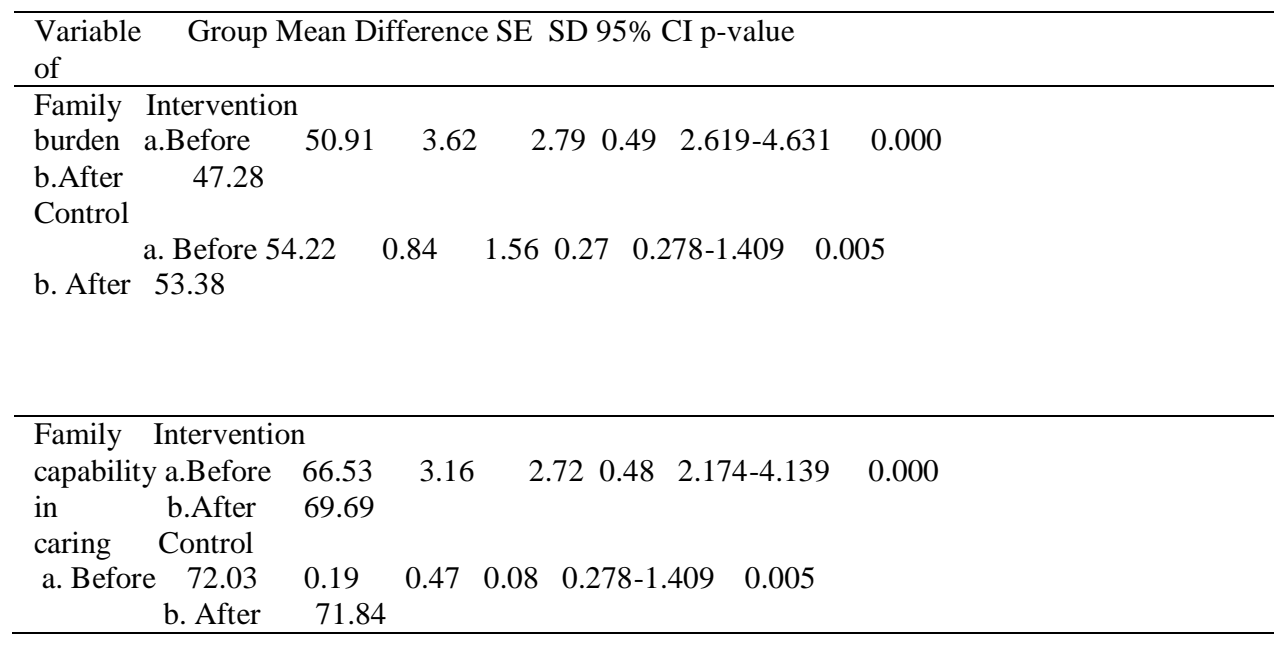

Table 12 Differences of Family Burden and Capability in Caring for Children with mental Retardation in Intervention and Control Group

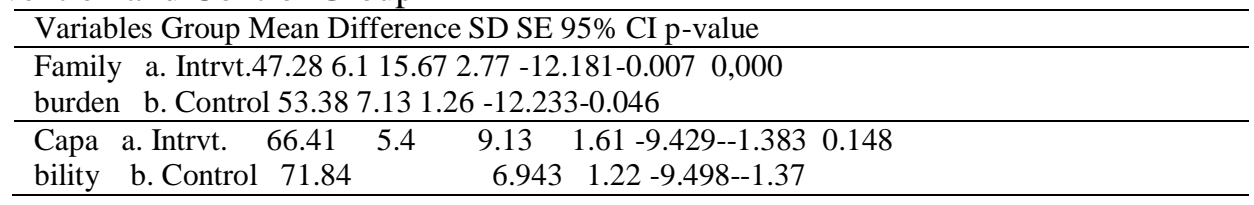




\section{DISCUSSION}

\section{Characteristics of Parents of Mental Retardation Children}

The results showed the average age of parents who have children mental retardation is 42.28 years. Most parents are poorly educated, income under UMP with family type mostly in the form of nuclear family. The same study showed parents of mentally retarded children in Central Java aged 33-42 years (41.9\%) (Reni, 2012). The majority of parent education of mentally retarded children in Surakarta is SMA (53.3\%) (Emmanuel, 2010). The education of parents of mentally retarded children in Sumedang has high school education (58.3\%), earning between Rp.600.000 to Rp. 1,000,000 (95,5\%) with large family type $(72,7 \%)$ (Sutini et al, 2009).

Based on the results above the age of the parents an average of 42.28 years, according to the psychosocial theory of Erikson that age is in middle adulthood. By the name of adulthood, at this stage, the individual has reached the culmination of the development of all his abilities. His knowledge is quite extensive; his skills are quite large, so the individual development is very rapid. Although the knowledge and abilities of the individual are extensive, he can not master all kinds of knowledge and skills, so that his knowledge and skills are limited. To do or achieve certain things he experienced obstacles. This time, they focus on career and family (Desmita, 2012).

According to Davis and Newstrom (2004) in Kurniadi (2013) that older parents are more experienced in adapting to the environment, work and age are often assumed with decreased ability in speed, dexterity, strength, and coordination. This is possible, because when viewed regarding cognitive, then people with younger age will better capture information and will more easily also in practice a skill, which in this case is the skill or ability of the family in the care of children mental retardation.

Age will affect a person's physical condition, spirit, burden, capacity to care, responsibility both at work and in everyday life. Changes in age will affect the tendency to use mental health services where the age increases a person the greater the trust to seek help to health services. The behavior of seeking such help peaks in the 25-45 year age range and decreases with age (Desmita, 2012).

Researchers analyzed that the age of parents with children mental retardation averaged 42.28 years or in middle adulthood. At this age, a lot of business and activities to be done by parents so that with this age attention is given to children is still small. In addition to this age, parents have little experience to recognize problems in children. Therefore, parents should increase the quantity and quality when interacting with the child so that the problems experienced by children can be reduced or overcome.

The level of education is an experience that serves to develop the capability and quality of a person's personality, where the higher the education level, the more likely to take advantage of knowledge and skills (Siagian, 2001, in Kurniadi, 2013). Based on the theory Notoatmodjo (2003), that education, in general, can change thought patterns, patterns of behavior and decision-making patterns. The higher a person's education, the more mature patterns of thought and behavior of a person. Education is a process of learning outcomes in an educational institution with various levels of education.

A person who has a high education will have a high cognitive development as well, so hopefully, someone can receive information well. The level of education is very influential on the program of increasing knowledge directly and indirectly to the behavior. Although the degree of education is not the only factor that supports a person's mindset with the high education of a person, it will tend to be more receptive to change that is good while someone who does not have a basic level of continuing education will be closed and difficult to accept change.

A person's education level is related to the ability to receive information and relate to their attitudes in acquiring knowledge. The level of education also has an influence on one's understanding of the problem at hand. Higher education can provide higher knowledge to the individual so that it can produce good habits in the effort to maintain health. When individuals are aware of their health, they tend to seek immediate help to solve the problems they face. A number of studies have identified the importance of 
education as a source of coping and prevention of psychosocial problems; even education is more meaningful than income levels in determining the use of health facilities (McCubbin, 2003).

Education becomes a measure of a person's ability to interact with others effectively. A person with higher education will more easily receive information, easy to understand and easy to solve problems. Individuals with higher education have wider knowledge and more frequent use of health facilities than low education. For that, the lower the education of parents the less good the ability of parents in caring for children mental retardation resulting in the burden in the family. This suggests that education affects the knowledge or information obtained by parents about the symptoms experienced by the child's mental retardation that allows a person can not identify the stressor and overcome the problem.

Researchers analyzed that parents are educated low (SMA down) more than S1. Educational background is the basis of the parent's ability to take care of the child mentally disabled properly. Caring for children with mental retardation requires intellectual, technical and interpersonal skills based on formal education (Doengoes, 2000, in Ningsih, 2014). Family income also affects parents in caring for family members. This is evident in the results of research that proves that most parents have less income than UMP. Earnings greatly affect parents in meeting the needs of his family. Of income can also develop the individual's ability to increase the fulfillment of family needs. Families with low socioeconomic levels increase the prevalence of psychological disorders, such as anxiety, causing burden in the family, which will affect the treatment.

Parents who come from low socioeconomic families will experience an increase in anxiety compared with parents who come from families with middle and high socioeconomic status. However, parents feel that they can fulfill their parents' obligations to their children even though the jobs that provide income are under the UMP, but feel they can still fulfill their obligation to support their families. The level of family income greatly affects the adequacy or absence of primary, secondary needs and attention and affection that will be obtained by children (Andren,
2006). The economic situation of poor families is a factor that is less supportive of the growth and development of children. This is because the family income level is very influential on family food consumption (Asra, 2013). The nuclear family is more positive for children because the children get more attention from parents. The fewer the number of family members, the more therapeutic relationships that parents and children can build. The effectiveness of parental efforts in fulfilling the needs of child love will be more secure than families with more family members. Family integrity also affects stress levels in the elderly so that it can cause a burden on the family and will affect the child's mental retardation care. Single parent parents with mentally disabled children will experience more stress when compared with whole families.

In addition to age, the ability of family care of the mentally retarded child is also influenced by the socioeconomic level of the family as well as the family type. This can help the child's mental retardation in overcoming the problem takes a lot of money as well as the children from the small family receive more attention than the children of the extended family. Families are two or more individuals joined because of certain ties to share experiences and emotional approaches and identify themselves as part of the family. Family type is six. One type of family is the nuclear family of the family, husband, wife, and child (birth/adoption) (Friedman, 2010). Researchers analyzed that although most mentally retarded children have a nuclear family type, the child has not been able to achieve optimal development. This is because not yet optimal stimulation provided by parents. The need for optimal care in children with mental retardation with limited ability possessed. The fewer the number of family members the more opportunities to meet the needs that can be accepted by the child.

\section{Characteristics of Mental Retardation Children}

The results showed that the average age of children mental retardation was 11.38 years, mostly male sex with mild mental retardation classification. The same study showed an 11year-old child mental retardation in Surakarta $(16.67 \%)$ and most of the males (70\%) with mild mental retardation (70\%) (Emmanuel, 
2010). While the results according to Preodita (2008), showed mental retardation patients in Semarang male sex (85.2\%). The classification of mentally retarded children in Sumedang $86.4 \%$ was mild mental retardation (Sutini et al., 2009).

Based on the results above the age of mental retardation children an average of 11.38 years, according to psychosocial theory Erikson that age is at the age of school, at this time the child is very active to learn what is in the environment. The urge to know and do to the environment is enormous, but on the other hand because of the limitations of his ability and knowledge he sometimes faces difficulties, obstacles, and even failures. These barriers and failures can cause the child to feel inferior. When children are at this level, the social area extends from the family environment to the school, so all aspects have a role, for example, parents should always encourage, teachers should pay attention, friends must accept their presence, etc. (Fontaine, 2009).

.Children with mental retardation despite having reached school age are progressing slightly slower than normal size. The main difficulties are usually seen in school academic work, and many are problematic in reading and writing (Lumbantobing, 2011). Child mental retardation is sometimes unrecognized until middle age children where retardation is still mild. Age when starting to experience psychosocial problems is a powerful predictor of the prognosis of the disorder.

Age is closely related to the level of maturity or individual maturity (Townsend, 2008). The age of children is a period of development that extends from infancy to the age of five or six; this period is usually referred to as the preschool period, then develops on a par with the primary school year. The main cause of childhood is not due to mental retardation experienced by children at that age, but the lack of knowledge of parents in recognizing the symptoms of children who have mental retardation and the increasing age of children who are not accompanied by an increase in child development that makes parents late in recognizing problems in children .

Age is categorized into nine level, i.e. childhood (0-5 years), childhood (6-11 years), early adolescence (12-16 years), late adolescence (17-25 years), early adulthood
(26-35 years), late adulthood (36-45 years), early ages (45-55 years), the final elderly (5665 years) and the elderly 65 years and older (MOH, 2009). Researchers analyzed that most of the child's age of mental retardation at school age, which at this age demands a stage of development that should be owned by the child. Delay of parents in knowing the symptoms of mental retardation in children is the main cause. For that, parents need to do stimulation to achieve development in children.

The results showed that the difference in the number of mental retardation patients with male and female sex. Most people with mental retardation are male. This is allegedly due to mental retardation associated with gene mutations that occur on the $\mathrm{X}$ chromosome. Given the cause, child mental retardation with female sex is very small when compared with boys. Mental retardation associated with gene mutations that occur on $\mathrm{X}$ chromosome (Xlinked), to date has been identified more than 20 genes that allegedly led to X-linked mental retardation mental retardation.

The study says that there is indeed an anatomical difference between men and women in the inferior parietal lobe. In men, the lobe is about $10 \%$ larger than women. The parietal lobes are part of the cerebral cortex, the part of the brain that is highly correlated with visuospatial abilities (McCubbin, 2003). Gender is a biological and physiological difference that can differentiate between men and women. Men and women are a category of sex. While masculine and feminine are gender categories (Cartwright, M.E, 2007).

Researchers analyze that most people with mental retardation are male. This is because of the linkage to chromosomes. Men are regarded as the successor of generations within the family. But the problems experienced by boys with mental retardation can be overcome by providing special education to children.

Mental retardation is a disorder with various causes. These various causes can cause different degrees of mental retardation. The results showed that most children were mentally retarded in mild degrees. This is related to the detection of mental retardation of children at the age of schooling who have passed the time when children need the stimulation of development gained at the 
previous level of education so that mental retardation experienced to be light.

Factors of mental retardation are chromosomal abnormalities, pre and post natal injury, other genetic syndromes, fetal alcohol syndrome, intrauterine infection and congenital metabolic abnormalities. Other causes of mental retardation are the brain, genetic and environmental problems. Mild mental retardation (IQ 55-69), moderate mental retardation (IQ 36-54). The signs and symptoms of mental retardation are divided into level of intelligence, divided based on the results of intelligence quotient (IQ) (Sunaryo, 2011).

Researchers analyzed that most mental retardation children had mild mental retardation. It can be known through IQ. With mild mental retardation, usually, children also have a dependence in meeting the needs of fewer than heavy mental retardation. For that, parents can teach children to be independent by facilitating children to achieve its development.

\section{Family Expenses With Mental Retardation Children Before Given Intervention In Group Treatment And Control Group}

The results showed that the average burden of the family with the child's mental retardation before being given intervention in the treatment group was 50.91. While in the control group the average family load is 54.22 . Based on these results can be concluded by the standard family load in the category of the medium load.

Mental retardation, although not directly cause death, but will cause deep suffering for the individual and heavy burden for the family, both mental and material because the patient can no longer be productive. According to Drews (2011), children with mental retardation have a limited intellectual function will affect the ability to learn to solve the problem, the limitations of adaptive behavior function in the form of skills needed to live their daily life, the child is unable to communicate effectively. According to Hosseinkhanzadeh (2013), said mental retardation requires special attention. Therefore, children are highly dependent on the people around them, so the child is very dependent on the participation and full support of the family. Taylor (2011), said the form of family support is emotional attention, instrumental help, information, and judgment. Meanwhile, according to the American Association on Intellectual and Developmental Disabilities (AAID) said social support is important for people with mental retardation. Through the social support of parents, children are able to socialize with the environment. The burden that the family feels is due to the family's disappointment by having children with mental retardation. This is because there is no increase in family knowledge to understand the limitations and overcome problems in children mental retardation. The underlying concept of acceptable behavior is the assumption that mental retardation is an infectious, untreatable, and even dealing with it as a curse from God. This makes an exaggerated fear of mental retardation disorders called leprophobia (Boyd, 2008). The problems faced by child mental retardation is not only a medical problem but also a psychosocial problem. The psychosocial impact caused by mental retardation is so wide that it creates unrest not only by the children themselves but also for families, communities and the State. Child mental retardation not only suffered physical damage but also suffered psychosocially due to environmental behavior. Psychosocial problems of children mental retardation can be experienced either by the child's mental retardation, family, and society (Friedman, 2010).

Facing family members diagnosed with mental retardation is usually a family panic and trying to hide the child to be not known by the surrounding community or even alienate the child from the family for fear of contagion. Anxiety experienced by the family against the possibility of transmission will affect the role of the family in child care mental retardation (Lumbantobing, 2011).

The burden of the family experienced can be caused by psychosocial problems that arise in families with children who suffer from mental retardation. Children with much more mental retardation exhibit moderate and severe psychiatric abnormalities than children with normal intelligence. Research in Sweden found more than half of schoolchildren with mild mental retardation, nearly two thirds can suffer from psychiatric problems and severe behavior (Tomb, 2004). 
Expenses can be subjective or objective. The objective burden is related to client behavior, role appearance, widespread effects on the family, the need for support and costs incurred due to illness. The subjective burden is the feeling of being burdened by someone individual (WHO, 2009). Incompatibility parents expectations with the potential of the child tend to cause problems in the future in the process of child development. According Muttaqin (2011), said the family would give excessive protection to their children so that children get limited opportunities to get experience by the level of development. Researchers analyzed that most indicated that objected to caring for children was due to child dependence on others (parents). The objections should be avoided. Parents should be more trying to get closer to the child so that children can grow and develop by expectations.

\section{Family Ability in Caring for Child Mental Retardation Before Giving Intervention In Group Treatment And Control}

The results showed the average total family ability in caring for mental retardation children before being given intervention in the treatment group was 66.69 . Where the average ability of the family in terms of recognizing the problem is 12.38 . The average family ability in deciding the right course of action is 13.22. The average family ability to care for children is 15.66 . The average family's ability to modify the environment is 14.66 . While the average ability of the family in terms of utilizing health care facilities is 13.53. While in the control group the mean total ability of the family in caring is 72.03 . Where the average ability of the family in terms of recognizing the problem is 15.72 . The average family ability in deciding appropriate action is 16.47. The average family ability to care for children is 14.62 . The average family ability to modify the environment is 14.09 . While the average ability of families in terms of utilizing health care facilities is 11.12. According to Hartanto (2011), when individuals are aware of their health, they tend to seek immediate help to overcome the problems faced. Lack of knowledge of parents in recognizing the symptoms of children who have mental retardation causing parents late in recognizing problems in children, so it will be too late in the treatment. Children with the study period undertaken in school so that parents indirectly get the knowledge and information about how to care for children mental retardation.

Information provided by schools requires good application to parents at home. For that, parents need to improve their knowledge through psychoeducation therapy. Especially with the condition of mental retardation and problems that can appear good to self, family, and society around mental retardation. Therefore, the need for family support in the form of emotional support involves the expression of a sense of empathy towards someone that makes it feel better. Award support in the form of a positive response from people around him. Instrumental support in the form of support of the real nature of direct assistance (Taylor, 2011).

Education provided to the family is related to the medical diagnosis and nursing diagnosis experienced by the child. Family education can help families face stressors because of sick children, which has a positive effect on the child's condition. Communities have a great influence in the rehabilitation and recovery of children with mental retardation. Healthcare providers including nurses must undergo leadership roles in assessing the adequacy and effectiveness of resources in the community and in recommending changes to improve access and quality of mental health services. The whole family situation does have a profound effect on the health of each family member. The family load statement shows that the lack of a family's ability to care for a child's mental retardation.

Parents assess the limitations that exist in children is difficult to overcome, so parents do not bring children to do therapy. While for the socialization of children is prohibited because parents feel the lack of children can be a mockery material peers. Parents can improve the ability to care for a child's mental retardation by increasing knowledge about caring for a child's mental retardation through mass media as well as those from a child's school.

\section{Family Expenses With Mental Retardation Children After Given Intervention In Group Treatment And Control Group}


The results showed that the average burden of the family with the child's mental retardation after being given intervention in the treatment group was 47.09. While the control group average family load is 53.38. Based on these results can be concluded by the standard family load in the category of the medium load.

The same study in Jakarta showed that there were differences in family burden between before and after psychoeducation therapy (Nurbani, 2009). Meanwhile, according to research Sutini et al. (2009), in Sumedang also showed that the difference is coping parents after given self-help group therapy. Thus, from two studies above that to reduce the burden of parents with children mental retardation required an intervention that begins with the child's parents.

Although after psychoeducation therapy there are still families burdened with mental retardation children. This is due to the characteristics of parents affecting the outcomes of the implementation of psychoeducation therapy such as age and education. Where based on the results obtained that the age of parents with mental retardation children are in middle adulthood and low educated. By the name of adulthood, at this stage, the individual has reached the culmination of the development of all his abilities.

His knowledge is quite extensive; his skills are quite large, so the individual development is very rapid. Although the knowledge and abilities of the individual are very wide, he can not master all kinds of knowledge and skills, so that his knowledge and skills are limited. To do or achieve certain things he experienced obstacles. This time, they focus on career and family (Desmita, 2012).

In addition to the characteristics of age, education also affects where the level of education is an experience that works to develop the ability and quality of a personality, where the higher the level of education the greater to utilize knowledge and skills (Siagian, 2001, in Kurniadi, 2013). Based on the theory Notoatmodjo (2003), that education, in general, can change thought patterns, patterns of behavior and decision-making patterns. The higher a person's education, the more mature patterns of thought and behavior of a person.

Education is a process of learning outcomes in an educational institution with various levels of education. A person's education level is related to the ability to receive information and relate to their attitudes in acquiring knowledge. The level of education also has an influence on one's understanding of the problem at hand. Higher education can provide higher knowledge to the individual so that it can produce good habits in the effort to maintain health.

When individuals are aware of their health, they tend to seek immediate help to solve the problems they face. Some studies have identified the importance of education as a source of coping and prevention of psychosocial problems; even education is more meaningful than income levels in determining the use of health facilities (McCubbin, 2003).

In addition, because it is done in a short time and incidental so the result is less effective. However, this therapy will be more effective if done in a scheduled and continuous. Mental retardation if unknown and handled, in turn, will contribute to improving the "Burden Disease" (WHO, 2007). Child mental retardation has limited independence this is a burden for parents. Child dependence mental retardation becomes the main cause of stress felt by parents. Intervention, especially psychoeducation therapy, is needed to increase the knowledge of parents in responding to the child's limitations regardless of burden (Stuart and Laraia, 2009).

Principally psychoeducation helps family members in increasing knowledge about the disease through information and education that can support child treatment and lower the burden on the child's family of mental retardation (Levine, 2002). The main purpose of family psychoeducation therapy is to exchange information about mental health care from illness, help family members understand about the illness of their family members such as symptoms, medications needed to reduce symptoms and others (Varcarolis, 2012).

Psychoeducation meetings of families or some 
families provide shared feelings and strategies to share feelings with each other. The family psychoeducation group is very useful for mental problems and equally beneficial for medical or surgical diseases. Through the provision of family psychoeducation in this intervention group, it is expected to reduce the burden of families with children mental retardation (Miklowitz, 1998). A family is a group of individuals who interact, provide support and influence each other in performing basic functions so that the family burden decreases.

In families with one family member who has mental retardation, the health care function is needed by the child well in the form of support that can be provided by the family. With the lack of support provided by the family can cause a burden on the family (Shieves, 2005). Family members are the main parties who bear the burden of both the physical, emotional and financial burden of having one family member suffering mental retardation. The immediate impacts of family members include rejection or isolation by friends, neighbors, and communities that can result in family members tending to isolate themselves, limit themselves to social activities and refuse to participate in normal social life. Failure in social relations greatly affects family members in terms of availability of support from the social environment (Tomb, 2004).

Psychoeducation therapy is performed on families with mentally retarded children, whereas educational exercises acceptable to the child's mental retardation are in the best interests of developing the potential, correcting wrong attributes, teaching a skill so that the child can earn a living. Child training is more difficult than ordinary children because their attention is easily attracted to other things so should be given a colorful game, read, and everything must be seen, heard and touched (Judarwanto, 2010).

Exercises and education are given chronologically in the form of home exercises such as lessons about eating alone, and others. Exercises in schools such as social development, technical training are provided according to interests, sex, and social standing. The moral exercise of small children should be told what is good and what is not good. In order for him to understand then every disciplinary offense needs to be accompanied by punishment and every good deed needs to be accompanied by a prize (Juveska, 2007).

There is a decrease in the burden felt by parents in the intervention group. This is evident from the distribution of respondents' answers after the intervention based on the distributed questionnaires, from 38 respondents in the treatment group after the intervention was given, as many as $39.5 \%$ of respondents felt they had no opportunity to fulfill their personal desires for caring for children. While in the control group, $52.6 \%$ of respondents said they felt they were asking for more help than needed and were unable to care for the child any longer.

Although there is a decrease in the burden felt by parents, there are still parents who feel burdened, so it is better for the school to work together with public health center (Puskesmas) officers to carry out psychoeducation therapy activities. Then for health workers should make a service to families who have children mental retardation such as providing consulting services, forming a group of a selfhelp group (SHG), forming a peer review group, providing exercise training, home care. With the form of service is expected family can facilitate health service well so that family unencumbered with having a child of mental retardation, so that ability of family in doing maintenance also increase.

\section{Family Ability in Caring for Child Mental Retardation After Given Intervention In Treatment And Control Groups}

The results showed the average total family ability in caring for mental retardation children after being given intervention in the treatment group was 66.53 . Where the average ability of the family in terms of recognizing the problem is 12.25 . The average family ability in deciding the right course of action is 13.09 . The average family ability to care for children is 14.53 . The average family's ability to modify the environment is 13.44. While the average ability of families in terms of utilizing health care facilities is 12.56 .

While in the control group the mean total ability of the family in care was 71.84 . Where the average ability of the family in terms of 
recognizing the problem is 15.72 . The average family ability in deciding appropriate action is 16.47. The average family ability to care for children is 14.53 . The average family ability to modify the environment is 14.00 . While the average ability of families in terms of utilizing health care facilities is 11.12 .

The same study in Jakarta showed that the increasing ability of a family to care for family members after psychoeducation therapy (Ruti et al., 2010). Meanwhile, according to research Asra (2013), in North Sumatra showed an increase in child knowledge of mental retardation after psychoeducation therapy in the elderly.

Thus, from the two studies above that psychoeducation therapy has a good influence in improving knowledge of parents. With increasing knowledge of the parents in caring for mentally retarded children, it will also increase the quality of care given by parents to children with mental retardation that can indirectly increase the ability of children to be more independent. Therapy is done on the family to cope with children with mental retardation that is individual therapy, family, and group. Among individual psychotherapy is a therapy performed to reduce stress, the crisis in children. Family therapy in the form of psychoeducation focus therapy views the individual as part of the system in the family. Behavioral therapy can be done if the client behavior is under control, to intervene in individual behavior towards the better, so it gives the feeling of living or family mental health (Townsend, 2008).

The main purpose of family psychoeducation therapy is to exchange information about mental health care due to an illness suffered, help family members understand their family members as disease symptoms, treatment is needed to reduce symptoms and others. Psychoeducation meetings of families or some families provide shared feelings and strategies to jointly share perceived feelings (Varcarolis, 2012).

Family psychoeducation groups are beneficial for mental, medical or surgical illnesses. Families who previously felt burdened and therefore contributes to a mentally retarded child care provision but after being given the family, psychoeducation therapy does not feel burdened so a family capable of taking care of the mentally disabled children.

The ability to care in terms of 5 family health tasks are able to recognize family health problems, able to decide the right action for a sick family, able to care for children who have health problems include stress management, able to modify the family environment and families are able to utilize health care facilities (Friedman, 2010). There was an increased ability after psychoeducation therapy in the intervention group. It is seen in the distribution of respondents' answers based on the ability questionnaire were in the treatment group that is as much as $63.2 \%$ of respondents said to train children to meet their daily needs. While in the control group, as many as $76.3 \%$ of respondents said children are taught to read, write correctly.

Not all family capacities change even after being given intervention. According to Surasvati (2012), this is influenced by several factors that inhibit the ability of the parents such as age, involvement, education, previous experience of parenting, the stress of parents and relationship of husband and wife. Wong (2009), said there are 3 factors namely difficulties in receiving children mental retardation, medical matters, fatigue in caring.

Based on the results of research that characteristic of the age of the parents is in middle age with low educated. In accordance with the name of adulthood, at this stage, the individual has reached the culmination of the development of all his abilities. His knowledge is quite extensive; his skills are quite large, so the individual development is very rapid. Although the knowledge and abilities of the individual are very wide, he can not master all kinds of knowledge and skills, so that his knowledge and skills are limited. To do or achieve certain things he experienced obstacles. This time, they focus on career and family (Desmita, 2012).

In addition to the characteristics of age, education also affects where the level of education is an experience that works to develop the ability and quality of a personality, where the higher the level of education the greater to utilize knowledge and skills (Siagian, 2001, in Kurniadi, 2013). Based on 
the theory Notoatmodjo (2003), that education, in general, can change thought patterns, patterns of behavior and decision-making patterns. The higher a person's education, the more mature patterns of thought and behavior of a person.

Education is a process of learning outcomes in an educational institution with various levels of education. A person's education level is related to the ability to receive information and relate to their attitudes in acquiring knowledge. The level of education also has an influence on one's understanding of the problem at hand. Higher education can provide higher knowledge to the individual so that it can produce good habits in the effort to maintain health. When individuals are aware of their health, they tend to seek immediate help to solve the problems they face. A number of studies have identified the importance of education as a source of coping and prevention of psychosocial problems; even education is more meaningful than income levels in determining the use of health facilities (McCubbin, 2003).

Researchers analyzed that in addition to reducing the burden of respondents, psychoeducation therapy can improve the ability of families in caring for children mental retardation. For that, psychoeducation therapy can be used on a scheduled and continuous basis.

\section{Differences in Family Expenses In Group Intervention, Control Before And After Treatment Provided}

The results showed that the intervention and control group decreased the family burden from before and after psychoeducation therapy.

Based on the results of the study it was found that the family burden decreased after psychoeducation therapy but did not increase the ability to care for children mental retardation, this is because in SDLB there are meeting activities of parents who have children mental retardation although the meeting is not done routinely. Where at the meeting the parents get information about the progress and development of children during school children.
The school also gives support and encouragement to the parents that parents should not be shy, anxious, worried and so forth with having children mental retardation. Although mentally disabled children have limited intellectual, communication, difficulty performing basic activities of daily life and others but parents should always teach and train their children at home and not just depend on the school so that children can be independent.

The decrease in family burden shown in this study is consistent with the results of a study conducted by Hasmila (2011), in Aceh on the influence of Family Psychoeducation therapy on the burden and ability to the family caring for the client of the statue shows that there is a decrease in family burden and the increase of family ability in taking care after therapy, Whereas according to Ahmmed research, M. (2011), in Bangladesh about Impact of PsychoEducation and Support Program for Parents of Children with Intellectual Disability research result obtained ability of parent with child of mental retardation have significant increase with result $-7,21 p<0.001$. Thus, from the two studies above that, both groups had an effect on the parental burden of the children with mental retardation, the intervention group had a large margin when compared to the control group.

Psychoeducation therapy can increase family's knowledge about the disease, provide family support, the family can express the perceived burden of providing long treatment for family members. (Miklowitz, 1998). Psychoeducation is a treatment modality delivered by professionals, who integrate and synergize between psychotherapy and educational intervention (Cartwright, 2007). This therapy is given to individuals or families with psychological disorders, especially for patients with schizophrenia, depression, anxiety, mental disorders, eating disorders, personality disorders and can also be given to patients suffering from a physical illness (Stuart \& Laraia, 2009).

Several research results indicate that psychoeducation intervention can decrease the symptoms of mental health problems, in particular, can decrease anxiety, depression. Elements of the plan include signs and 
symptoms, natural processes of disease, possible etiology, diagnostic tests, and actions, indicated lifestyle changes, treatment options, expected outcomes, treatment side effects, therapeutic strategies, adaptive coping responses, self-care (Miklowitz, 1998).

Based on the distribution of respondents' answers that with psychoeducation therapy a decrease in the burden felt in treating a child's mental retardation. To that end, the school can facilitate parents with children mental retardation in doing psychoeducation therapy. With the reduced burden felt by parents in caring for the child's mental retardation, there will be a more effective interaction between parent and child.

\section{Differences in Family Ability in Caring for Mental Retardation Children in Intervention Groups, Control Before And After Treatment}

The results showed that the intervention group had an increase in the ability to care for the mentally retarded child after therapy, while in the control group there was a decrease in the ability to care for the child's mental retardation after psychoeducation therapy.

Based on the results obtained that the ability of parents after psychoeducation therapy has decreased, this is because in terms of therapy between therapists do not perform equivalence tests so that there could be differences in therapy. In addition to the therapeutic process of therapy therapy comes home each parent who has a child mentally retardation, where sometimes the therapist finds a parent's house is not conducive to therapy, then the implementation of therapy between 45 to 60 minutes so that parents can not concentrate To the implementation of therapy.

The therapist found there were some parents who requested permission in the conduct of therapy for urgent needs and were replaced with other family members. At the time of the implementation of psychoeducation therapy did not do general therapy first, so the therapist found there are some parents who do not know about problems that occur in children so do not know how to care. There is a therapist who in the implementation of therapy by combining between session one and session two.
Not all family capacities change even after being given intervention. This is due to the characteristics of parents affecting the outcomes of the implementation of psychoeducation therapy such as age and education. Where based on the results obtained that the age of parents with mental retardation children are in middle adulthood and low educated. In accordance with the name of adulthood, at this stage, the individual has reached the culmination of the development of all his abilities. His knowledge is quite extensive; his skills are quite large, so the individual development is very rapid. Although the knowledge and abilities of the individual are very wide, he can not master all kinds of knowledge and skills, so that his knowledge and skills are limited. To do or achieve certain things he experienced obstacles. This time, they focus on career and family (Desmita, 2012).

In addition to the characteristics of age, education also affects where the level of education is an experience that works to develop the ability and quality of a personality, where the higher the level of education the greater to utilize knowledge and skills (Siagian, 2001, in Kurniadi, 2013). Based on the theory Notoatmodjo (2003), that education, in general, can change thought patterns, patterns of behavior and decision-making patterns. The higher a person's education, the more mature patterns of thought and behavior of a person. Education is a process of learning outcomes in an educational institution with various levels of education.

A person's education level is related to the ability to receive information and relate to their attitudes in acquiring knowledge. The level of education also has an influence on one's understanding of the problem at hand. Higher education can provide higher knowledge to the individual so that it can produce good habits in the effort to maintain health.

When individuals are aware of their health, they tend to seek immediate help to solve the problems they face. A number of studies have identified the importance of education as a source of coping and prevention of psychosocial problems; even education is more meaningful than income levels in determining the use of health facilities (McCubbin, 2003). 
The improvement of family ability in caring for mentally retarded children shown in this research is in line with the results of Hasmila (2011) study, in Aceh about the influence of Family Psychoeducation therapy on family's burden and ability to care for the client of the parent shows decrease of family burden and the improvement of family ability in taking care after Given therapy.

Meanwhile, according to Ahmmed research, M. (2011), in Bangladesh about Impact of Psycho-Education and Support Program for Parents of Children with Intellectual Disability research results obtained the ability of parents with children mental retardation had a significant increase with the result $-7.21 \mathrm{p}$ $<0.001$. Thus, from the two studies above that psychoeducation can be used to lower the burden and improve the ability of care families in mental retardation both in the intervention and control groups. Limitations of the child's mental retardation cause a high dependence on the people around him. Child and adolescent mental retardation will largely depend on the full participation and support of the family. The form of family support consists of 4, namely emotional attention, instrumental assistance, information, and assessment. The American Association on Intellectual and Developmental Disabilities (AAID) says social support is important for people with mental retardation. Through the social support of parents, children are able to socialize with the environment. The family's ability to care for a child's mental retardation in terms of psychoeducation therapy sessions such as the family is able to do the family problem assessment, the family's ability to do the maintenance. Family stress management ability, family burden management capability, and community empowerment help the family (Nursing Team of Universitas Indonesia, 2014).

According to Surasvati, (2012) family, ability in child care mental retardation can increase children independence, but this is influenced by several factors such as age, involvement, education, previous experience of parenting, the stress of parents and relationship of husband and wife. There are several other factors that also affect the ability of families in caring for children mental retardation is the difficulty in receiving children mental retardation, medical terms, fatigue in nurturing (Wong, 2009).

Efforts to improve the family's ability to care for children with mental retardation include explaining, demonstrating ways of identifying problems and motivating issues, providing health education, socialization, psychoeducation, information on using health facilities (Utami, 2013).

Respondents' answers to some of the questions posed indicated that psychoeducation therapy improved the respondent's ability to care for a child's mental retardation. Parents with a child with mental retardation should be able to continue therapy in order to increase the ability of parents to care for children while at home. Researchers analyze that with the increased ability of parents to care for children mental retardation, then the independence to be achieved more easily achieved children.

\section{Differences in Burden and Family Ability in Caring for Child Mental Retardation Between Group Intervention And Control}

The results showed that there were differences in the burden felt by parents between the intervention and control groups after psychoeducation therapy. In the variable of family ability in caring for mentally retarded children, it was found that there was no difference in family ability in treating mentally retarded children in intervention and control group after psychoeducation therapy. A decline in family burden and increase the ability of families in caring for mentally retarded children in the intervention group were visible from the mean value. Where the intervention group is given treatment in the form of psychoeducation therapy to the homes of each family. While in the control group given therapy in groups and also get information from the school. The decrease in family burden shown in this study is consistent with the results of the Hasmila (2011) study, in Aceh on the influence of Family Psychoeducation therapy on the burden and the ability of the families to care for the client's clients indicates that there is a decrease in family burden and the increased ability of the family to care after therapy.

According to research Ahmmed, M. (2011), in Bangladesh about Impact of Psycho-Education 
and Support Program for Parents of Children with Intellectual Disability research results obtained the ability of parents with children mental retardation had a significant increase in the results $-7.21 \mathrm{p}<0.001$. From the results of research obtained and reinforced by previous research indicates that psychoeducation therapy can reduce the burden felt by parents of children mental retardation and improve the family's ability to care for children mental retardation. Thus, to lower the family burden and improve the family's ability further, the school should continue the therapy by making the implementation schedule and disseminating the results of research, so that the child's parents feel interested in following psychoeducation therapy so that children can take care of mental retardation in a better direction.

\section{CONCLUSIONS}

The result is there is a decreasing of burden and the increasing of the family capability after treated with psycho-education therapy. It is recommended to do research that combines between psycho-education therapy and supportive of family psychosocial support for children with mental retardation.

\section{REFERENCES}

Ahmmed, M. (2011). Impact of PsychoEducation and Support Program for Parents of Children with Disability Intellectual. Thesis, University of Dakha, Bangladesh.

Asra. (2013). Efektifitas Psikoedukasi Pada Orang Tua dalam Meningkatkan Pengetahuan Seksualitas Remaja Retardasi Mental Ringan. Fakultas Psikologi UIN Sultan Syarif Kasim Riau. Jurnal Psikologi, Volume 9 Nomor 1, Juni 2013.

Behrman, Kilgman \& Arvin. (2000). Pediatrics Nelson, Jakarta. EGC.

Boyd, MA (2008). Psychiatric Nursing Contemporary Practice. Philadelphia: Lippincott,

Carson, VB (2000). Mental Health Nursing: The Nurse-Patient Journey. Philadelphia. WB Sauders Company.
Cartwright, M.E. (2007). Psychoeducation Among Caregivers Of Children Receiving Mental Health Services. Dissertation. Ohio ; Graduate School Of The Ohio State University

Dahlan, MS (2010). Large Samples And How Sampling In Medicine And Health Research. Jakarta: Salemba Medika,

Department of Social Welfare. (2015). Annual Report Jambi City. Unpublished.

Desmita. (2012). Psikologi Perkembangan. Bandung: PT Remaja Rosdakarya

Drews, Carolyn D. (2011). Variation In The Influence Of Selected Sociodemographic Risk Factors For Mental Retardation. Journal Of Public Health, Vol. 85, No.3 Mar 1995; 85,3; Proquest.

Dixon, et.al. (2013). Evidence-Based Practices For Services To Families Of People With Psychiatric Disabilities. Psychiatric Services. 52, 903-910.

Emmanuel. (2010). Hubungan Inteligensi Dengan Kematangan Sosial Pada Anak Retardasi Mental Di SLB/C Surakarta. Skripsi. Fakultas Kedokteran Universitas Sebelas Maret Surakarta.

Fontaine, KL (2009). Mental Health Nursing. New Jersey: Pearson Education. Inc.

Friedman, Marilyn M., Bowden, VR, \& Jones, EG (2010). Textbook of Family Nursing Research, Theory and Practice. Interpreting, Achir Yani S. Hamid et al.; Editor of the Indonesian edition, Estu Tiar. - Ed. $5^{\text {th }}$ Jakarta: EGC.

Hasmila, Sari. (2011). Effects of Therapy Against Family psychoeducation Expenses And Caring Family Capabilities Clients airborne In Bireuen District of Aceh. Thesis. University of Indonesia.

Heward, WL (2011). Exceptional Children: An Introduction to Special Education (5th ed.). New Jersey: Prentice Hall.

Judarwanto, Dr. Widodo. (2010). Retardasi Mental: Pencegahan dan Penanganannya. Diakses dari: http://www.koranindonesiasehat.wordpres s.com tanggal 20 Maret 2015.

Juveska. (2007). Retardasi Mental. Diakses dari: http://www.juveska.com tanggal 22 Maret 2015.

Kathleen Fisher. (2004). Health Disparities and Mental Retardation. Journal of Nursing Scholarship, pg.48 First Quarter 
2004; 36, 1; Proquest Health Management.

Lumbantobing. (2001). Children With Mental Retarded. Jakarta: Balai Publisher FKUI.

Levine, I.S. (2002). Family Psychoeducation-

Functioning, Effects, Therapy, Adults,

Person, People, Medication Personality.

Diakses Dari:

http://www.minddisorders.com/Del-

Fi/Family- Psychoeducation.html Tanggal 18 Maret 2015.

Maramis, WF (2011). Notes of Medical Science of the Soul. Matter 9. Surabaya: Airlangga University Press.

Miklowitz, David J. (1998). Developing Family Psychoeducational Treatments For Patients With Bipolar And Other Severe Psychiatric Disorders. Journal Of Marital And Family Therapy; pg. 491 Oct 1998; 24,4; Proquest Sociology

Muttaqin. (2011). Textbook of Nursing Impaired Respiratory System. Jakarta: Salemba Medika.

Ningsih, A.R.M. (2014). Hubungan Fungsi Pengorganisasian dengan

Pelaksanaan Kewaspadaan Standar Oleh Perawat Pelaksana di Rumah Sakit Umum Daerah Batu Sangkar. Tesis. FKEP Unand.

Nurbani. (2009). Pengaruh Psikoedukasi

Keluarga Terhadap Masalah

Psikososial Ansietas Dan Beban

Keluarga Dalam Merawat Pasien

Stroke Di RSUPN. Cipto

Mangunkusumo. Tesis. FIK-UI.

Rafiyah, W., and H. Suttharangsee Sangchan, (2011). Burden On Family Caregivers Caring For Patients With Schizophrenia. Nurse Media Journal Of Nursing, 1, 1, January 2011, 29-41.

Schwartz. (2011). Guidelines for ClinicalPaediatrics.Jakarta: EGC,

Shives, L. R. (2005). Basic Concepts of Psychiatric-Mental Health Nursing. Lippincott: William Wilkins

Stuart, GW, \& Laraia, MT (2009). Principles And Practice Of Psychiatric Nursing $9^{\text {th }}$ Ed. St. Louis: Mosby Year Book.

Sunaryo. (2011). Psychology For Nursing. Jakarta: EGC.

Sutini. (2009). Pengaruh Terapi Self-Help Group Terhadap Koping Keluarga Dengan Anak Retardasi Mental Di SLB-C Kabupaten Sumedang Tesis. FIK-UI.
Townsend, CM (2008). Essentials Of Psychiatric Mental Health Nursing. $4^{\text {th }}$ ed. Philadelphia: FA Davis Company.

Tomb, A.D. (2004). Buku Saku Psikiatri. Edisi 6. Jakarta: EGC.

Taylor, H.L.(2011). Manajemen Waktu (terjemahan Susanto Budhidarmo). Jakarta: Bima Rupa Aksara Jakarta: Balai Pustaka.

Utami, Yuniara Rastiyani. (2013). Adjustment And Parenting Children of Parents Who Have Mental Retardation. Thesis. Faculty of Psychology, Muhammadiyah University of Surakarta.

Varcarolis, EM (2012). Psychiatric Nursing Clinical Guide: Assessment Tools And Diagnosis. Philadelphia. WB Saunders Co.

Videbeck, SL (2007). Psychiatric Mental Health Nursing. (4rd Ed). Philadelphia: Lippincott Williams \& Wilkins.

WHO. (2007). The Lancet. London. Elsevier Properties SA.

Workshop Psychiatric Nursing 8th. Nurses Study Program Specialist Psychiatric Nursing Faculty of Nursing, University of Indonesia. (2014). The module Therapy Psychiatric Nursing. 